\title{
WORKLOAD, NECK AND UPPER LIMB PAIN IN SALVADOR'S POPULATION, BAHIA, BRAZIL
}

\author{
Katia Nunes Sá PhD, Postgraduation Department, \\ Bahiana School ofMedicine and \\ Public Health, Salvador, Bahia, Brazil \\ Abrahão Fontes Baptista \\ $\mathrm{PhD}$, Biomorphology Department, \\ Universidade Federal da Bahia, Salvador, \\ BA, Brazil. \\ Israel Souza MSc, Mathematics Department, Exact \\ Sciences Institute, Universidade Federal \\ Rural do Rio de Janeiro, Rio de Janeiro, \\ RJ, Brazil. \\ Marcos Almeida Matos \\ $\mathrm{PhD}$,Postgraduation Department, \\ Bahiana School of Medicine and \\ Public Health, Salvador, Bahia, Brazil. \\ Ines Lessa $\mathrm{PhD}$, Public Health Institute, \\ Universidade Federal da Bahia, Salvador, \\ BA, Brazil.
}

\begin{abstract}
Objectives: To describe the populational profile of adults affected by neck and upper limb pain (NULP) and to relate the characteristics of this type of pain with the predominantly physical, psychic and mixed workloads. Methods: A cross-sectional study was conducted in a sample of 2,297 individuals of $\geq 20$ years old, in SalvadorBrazil. A standardized questionnaire was applied to collect data about socio-demographic characteristics. Workers were grouped according to predominantly physical, psychic and mixed workloads, and associations were verified against the characteristics of those affected in comparison to individuals without reports of pain in the neck and upper limbs. The prevalence of pain was estimated by the OR adjusted (95\% CI). Univariate analyses and logistic regression were performed. Results: NULP was found in 222 individuals (9.47\%), and predominated in women and widowers exposed to physical workloads; moderate alcohol consumption was the protector in this occupational condition; for psychic workloads, being a woman and belonging to high social class appeared to be associated with the presence of pain in the region; for mixed workloads, being single appeared as a factor with less chance of association with NULP. Conclusion: NULP presents high populational prevalence, and workloads can influence such conditions. Being a woman or widow exposed to physical loads increase the risk of having NULP; When the worloads are psychic, the same occurs to women and people at higher social levels. Moderate use of alcohol was associated with less chance of NULP for physical load and being single, for mixed load.
\end{abstract}

Keywords: Epidemiology; Prevalence; Work. Labor.

\section{INTRODUCTION}

The work process presents innumerable situations that expose workers to continual weariness that occasionally generates loss of satisfactory job conditions. ${ }^{(1)}$ Each professional activity involves a series of activities that are characterized by organizational and ergonomic actions of this process and its environment, and which can be associated with various risk 
factors. To study these associations, populational researches must be supported by defined parameters to group the study population.

An alternative for grouping workers is by analysis of the load they are submitted to during work activities. The notion of workload (WL) has been presented as the most complete form of analyzing labor conditions. ${ }^{(1,2)}$ This concept is differentiated from risk factors by its amplitude, since it considers the complexity of biopsychosocial conditions involved. ${ }^{(3)}$ The concept of WL is related to the concept of worker weariness, however, it is not a territory of consensus in the literature, and therefore there are various classifications of it. However, there is consensus among authors that WLs are composed of subjective and objective elements that affect the worker's physical body and psyche. ${ }^{(4-6)}$ The complexity of precise determination of WLs leads to a difficulty in gauging them, which is only possible at the collective level, which places epidemiology in a fundamental and indispensable role in the study of the worker's health. ${ }^{(7)}$

One of the greatest consequences of inadequate exposure to WLs is the presence of musculoskeletal pain. This association leads to difficulties in studying it, since pain also constitutes a complex, multidimensional and subjective phenomenon that comprises sensorial, affective, interpretative and behavioral dimensions. ${ }^{(8)}$ The presence of pain may be associated with occupational conditions, particularly when they affect the cervical and upper limbs, regions that present high prevalence records, especially in groups of workers. ${ }^{(9)}$ The prevalence of neck pain has presented a range of $9.5 \%$ to $65.4 \%{ }^{(10)}$ and in upper limbs of $7 \%$ to $26 \%$. $^{(11)}$

In the worker population, work-related osteomuscular disturbances figure among the most prevalent diseases. In Brazil, especially in the Northeast, there are innumerable nonformal occupational activities that present unknown conditions from the point of view of the worker's health. ${ }^{(12)}$ Therefore, the aim of this study, in addition to describing the populational profile of adults affected by pain in the neck (cervical region) or upper limbs (NULP), it was to relate the characteristics of this type of pain with the predominantly physical, psychic and mixed workloads.

\section{MATERIAL AND METHODS}

This cross-sectional populational enquiry was conducted in 1999 - 2000, in the adult population of Salvador - Bahia, Brazil, by investigators of chronic, non-transmittable diseases of the Collective Health Institute of UFBA ("Instituto de Saúde Coletiva da Universidade 
Federal de Bahia - UFBA"). The instrument included a section of questions about chronic pain that has been used by researches in the post graduation program of the "Escola Bahiana de Medicina e Saúde Pública.” (Bahian School of Medicine and Public Health).

The city of Salvador is divided into areas represented by 10 hydrographic basins, and 2 of these did not participate in the sampling process, due to presenting very low demographic density. To develop the present study, the census sectors of the other 8 basins were grouped into 108 research areas, classified by socio-economic level into high, mixed and low. By probabilistic sampling, 34 of these areas were drawn proportionally to the number of sectors of each social class. The areas drawn contained 16,592 domiciles, with around 229,162 inhabitants, 112,290 of them of an age higher than or equal to 20 years. ${ }^{(13)}$

As the amplitude of variation in prevalence described in the literature for NULP is very high, the estimated prevalence for this study was $25 \%$, level of confidence $95 \%$ and delineation error of $2 \%$, and the number of individuals to reply to the investigation question was estimated as 1,800. The sample was overestimated at 2,500 adults, by reason of the expected losses due to uninhabited homes, empty plots, non-residential construction and residents' absence due to traveling, work or not being located in 3 consecutive visits. The estimated mean in 1.7 eligible persons per residence was extracted in a systematic sample (interval - 10) of 1,470 domiciles, respecting the socio-economic level and populational density of the areas. The number of families that agreed to participate amounted to 1,258. There were 72 refusals $(2.9 \%)$ by the eligible member drawn in the residence, which generated a data base with a total of 2,297 individuals interviewed.

After signing the term of free consent, the participants answered the pre-tested the questionnaire that was divided into 10 modules. The modules involved questions about personal identification, information about the domicile, socio-demographic data, life habits, physical activities and pain.

Stratification of the variables was determined as follows:

1) Age: young adults (from 20 to 34 years of age), middle-aged adults (from 35 to 64 years of age) and the elderly (over 65 years of age);

2) Marital status: married, single, separated/divorced and widowed;

3) Race/ethnicity: white, dark/mulatto, black/negro, by self-definition of the skin color, in accordance with the manner used officially in the demographic census of the country; 
4) Social Class: According to the classification of the "Associação Brasileira de Pesquisa de Mercado ABPEME" (Brazilian market research association) and afterwards grouped into the categories high $(\mathrm{A} 1+\mathrm{A} 2+\mathrm{B} 1)$, middle $(\mathrm{B} 2+\mathrm{C})$ and low $(\mathrm{D}+\mathrm{E})$

5) Educational level: low (illiterate + know how to read and write, but never went to school + those that attended school for up to four years of primary schooling), middle (from five to ten years of schooling) and high (minimum of 11 years at school);

6) Alcohol consumption: excessive: consumption at weekend with frequent inebriation and/or daily consumption with or without inebriation; moderate for those who drank up to once a week without inebriation and do not drink for those who have never drank;

7) Smoking: current smoker, ex-smoker and non-smoker.

8) Physical activity: moderately active persons - those that mention practicing at least three hours a week of some of the following leisure activities: walking, dancing, swimming, pedaling, running or other sporting activity; intense activity - training for competitions (minimum of 2 hours daily); sedentary-all the others.

9) Period of being affected by pain: acute (less than 6 months) and chronic (over 6 months) according to IASP;

10) Pain location: Mooney's body map. ${ }^{(14)}$

11) Occupation: The types of occupation mentioned, the great majority of them non-formal, were incompatible with the classification of the Brazilian Occupational Code ("Código de Ocupação Brasileiro - COB”), except for Group GG5 (workers in services, commercial sales persons in stores and markets). Therefore, it was opted to analyze the occupational categories by the workload that was stratified as follows: Physical - Occupations that involved intense bodily activities (e.g.: nursing aids, hairdressers, motor mechanics, house maids, general service assistants, painters, industrial operators); psychic - activities of a more intellectual and relational nature (e.g.: receptionists, draftsmen, secretaries, bus ticket collectors, counter attendants); and mixed - activities that involved both physical and psychic load without one predominating over the other (e.g.: soldiers in the army, home-based clothes salespersons, laboratory representatives).

The dependant variable was the presence of NULP. The independent variable was the category of the occupational load and the following were studied as co-variables: sex, age, marital status, physical activity, educational level, socio-economic level, smoking and alcohol consumption. 
The variables were presented descriptively in absolute numbers and proportions, estimating the prevalence and IC at $95 \%$. For the univariate analyses, the Chi-square test was applied, afterwards proceeding with Multiple Logistic Regression to verify the independent association between the study variables. For univariate analyses and for inclusion in the final regression model, the value of $\mathrm{p}<0.1$ was considered, both with an interval of confidence of 95\% and presentation of the unadjusted and adjusted Odds Ratios. In the final analysis with logistic regression the accepted alpha value was $5 \%(\mathrm{p}<0.05)$. The statistical package used was the program SPSS version 14.0. The project was approved by the Medical Ethics Committee of the Regional Council of Medicine of the State of Bahia (69.648/99 process number) and all the participants signed a Post-Informed Term of Consent, in accordance with the determination of the National Health Council Resolution 196/96.

\section{RESULTS}

The final sample was constituted of 2,297 individuals interviewed and as can be observed in Table 1 , mean age of $40.91 \pm 14.73$ years. The mean central obesity index was $81.99 \pm 11.74 \mathrm{~cm}$, a variable observed in $23.4 \%$ of the sample, being predominant in men.

Of the 222 individuals with NULP, 135 were women $(60.8 \%)$. It was observed that the greater part of persons with pain in the cervical segment or affecting the upper limbs, consisted of individuals between the ages of 35 and 64 years, of high educational level and social class. With regard to the types of workload in the affected individuals, the distribution was similar in the three segments analyzed - physical, psychic and mixed loads. To analyze the data in this study, only individuals that did not have any type of pain, and those that had NULP were used in the sample (Table 1), totaling a sample of 1,383 individuals for the present study.

Table 1 - Sample sociodemographic characteristics and prevalence of neck or upper limb pain

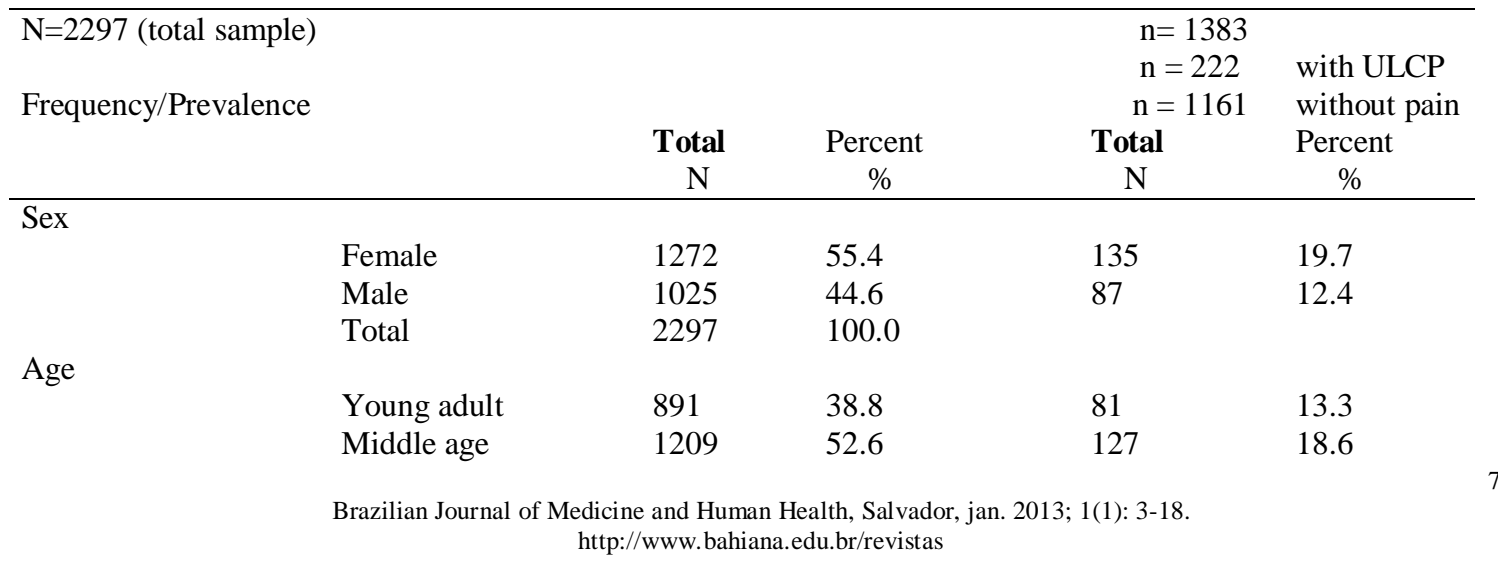




\begin{tabular}{|c|c|c|c|c|c|}
\hline & Elder & 197 & 8.6 & 14 & 15.7 \\
\hline & Married & 1474 & 64.6 & 142 & 16.3 \\
\hline & Single & 564 & 24.7 & 53 & 13.6 \\
\hline & Separate/divorciate & 111 & 4.9 & 10 & 18.5 \\
\hline & Widower & 133 & 5.8 & 15 & 25.4 \\
\hline \multicolumn{6}{|l|}{ Social class } \\
\hline & Low & 1250 & 54.4 & 107 & 14.4 \\
\hline & Middle & 848 & 36.9 & 85 & 16.5 \\
\hline & High & 168 & 7.3 & 25 & 23.4 \\
\hline \multicolumn{6}{|l|}{ Educational level } \\
\hline & Low & 978 & 42.9 & 96 & 18.1 \\
\hline & Middle & 1193 & 52.3 & 107 & 14.0 \\
\hline & High & 111 & 4.9 & 17 & 22.4 \\
\hline \multicolumn{6}{|l|}{ Skin color } \\
\hline & Mulatto & 1000 & 43.9 & 90 & 14.9 \\
\hline & White & 662 & 29.1 & 63 & 15.7 \\
\hline & Dark & 614 & 27.0 & 68 & 18.4 \\
\hline \multicolumn{6}{|l|}{ Smooking } \\
\hline & Smoker & 544 & 23.7 & 49 & 15.4 \\
\hline & Ex-smoker & 399 & 17.4 & 40 & 19.8 \\
\hline & No smoker & 1354 & 58.9 & 133 & 15.4 \\
\hline \multicolumn{6}{|l|}{ Alcohol } \\
\hline & Excessive consumer & 126 & 5.5 & 14 & 19.4 \\
\hline & Moderate consumer & 801 & 35.0 & 60 & 11.6 \\
\hline & No drinker & 1364 & 59.5 & 147 & 18.6 \\
\hline \multicolumn{6}{|l|}{ Central Obesity } \\
\hline & Yes & 531 & 23.4 & 49 & 17.4 \\
\hline & No & 1734 & 76.6 & 171 & 15.8 \\
\hline \multicolumn{6}{|l|}{ Physical activite } \\
\hline & Intense & 15 & 0.7 & 159 & 17.1 \\
\hline & Moderate & 269 & 11.7 & 38 & 16.5 \\
\hline & Light & 364 & 15.9 & 23 & 10.9 \\
\hline & No practitioner & 1644 & 71.7 & 0 & 0.0 \\
\hline \multicolumn{6}{|l|}{ Workload } \\
\hline & Physical & 1278 & 61.2 & 114 & 15.6 \\
\hline & Pshyquic & 703 & 33.7 & 75 & 16.6 \\
\hline & Mixed & 108 & 5.2 & 13 & 18.6 \\
\hline
\end{tabular}

When comparing subjects with NULP with individuals without reports of pain, one observed from the univariate analysis that they belonged to the female sex, were widowed and exposed to physical WLs that predisposed the individual to NULP. Moderate alcohol consumption was protective in this occupational condition (Table 2). When the load was predominantly psychological, belonging to the female sex and high social class appeared to be associated with the presence of pain in the region (Table 3). For mixed loads, being single appeared as the factor with least chance of association with the presence of NULP (Table 
Table 2 - Univariate analisys of physical workload and socio-demographics caractheristics (Gross Odds Ratio)

\begin{tabular}{|c|c|c|c|c|c|}
\hline $\mathrm{N}=1278$ & & $\begin{array}{c}\text { Frequency } \\
\text { (absolute } \\
\text { number) }\end{array}$ & $\begin{array}{c}\text { Prevalence } \\
\%\end{array}$ & $\begin{array}{c}\text { Gross OR } \\
\text { (CI 95\%) }\end{array}$ & $p$ \\
\hline \multirow[t]{3}{*}{ Sex } & & & & & 0.001 \\
\hline & Female & 68 & 20.3 & $1.93(1.28-2.90)$ & 0.002 \\
\hline & Male & 45 & 11.6 & 1.00 & \\
\hline \multirow[t]{4}{*}{ Age } & & & & & 0.420 \\
\hline & Elder & 9 & 16.1 & $1.21(0.55-2.66)$ & 0.623 \\
\hline & Middle age & 63 & 17.3 & $1.32(0.86-2.02)$ & 0.192 \\
\hline & Young adult & 42 & 13.6 & 1.00 & \\
\hline \multirow[t]{4}{*}{ Skin color } & & & & & 0.746 \\
\hline & Dark & 37 & 17.2 & $1.18(0.69-2.01)$ & 0.544 \\
\hline & Mulatto & 48 & 14.9 & $0.99(0.60-1.64)$ & 0.984 \\
\hline & White & 28 & 15.0 & 1.00 & \\
\hline \multirow{5}{*}{$\begin{array}{l}\text { Conjugal } \\
\text { situation }\end{array}$} & & & & & 0.081 \\
\hline & Widower & 11 & 31.4 & $2.70(1.26-5.77)$ & 0.010 \\
\hline & Separate/divorciate & 6 & 22.2 & $1.68(0.65-4.32)$ & 0.279 \\
\hline & Single & 31 & 15.0 & $1.03(0.65-1.64)$ & 0.874 \\
\hline & Married & 66 & 14.5 & 1.00 & \\
\hline \multirow[t]{4}{*}{ Social class } & & & & & 0.355 \\
\hline & High & 6 & 27.3 & $2.11(0.80-5.59)$ & 0.131 \\
\hline & Middle & 35 & 15.2 & $1.00(0.64-1.56)$ & 0.973 \\
\hline & Low & 70 & 15.1 & 1.00 & \\
\hline \multirow{4}{*}{$\begin{array}{l}\text { Educational } \\
\text { level }\end{array}$} & & & & & 0.219 \\
\hline & Low & 65 & 17.7 & $0.85(0.23-3.12)$ & 0.817 \\
\hline & Middle & 45 & 13.1 & $0.60(0.16-2.22)$ & 0.448 \\
\hline & High & 3 & 20.0 & 1.00 & \\
\hline \multirow[t]{4}{*}{ Smoking } & & & & & 0.272 \\
\hline & Smoker & 36 & 18.2 & $1.39(0.88-2.18)$ & 0.155 \\
\hline & Ex-smoker & 19 & 18.3 & $1.39(0.792-2.46)$ & 0.248 \\
\hline & No smoker & 59 & 13.8 & 1.00 & \\
\hline \multirow[t]{4}{*}{ Alcohol } & & & & & 0.003 \\
\hline & Excessive consumer & 8 & 21.6 & $1.16(0.51-2.65)$ & 0.710 \\
\hline & Moderate consumer & 30 & 10.3 & $0.48(0.30-0.76)$ & 0.002 \\
\hline & No drinker & 76 & 19.1 & 1.00 & \\
\hline \multirow[t]{3}{*}{ Central Obesity } & & & & & 0.870 \\
\hline & Yes & 22 & 16.1 & $1.04(0.62-1.73)$ & 0.869 \\
\hline & No & 90 & 15.5 & 1.00 & \\
\hline \multirow[t]{5}{*}{ Physical activity } & & & & & 0.197 \\
\hline & No practitioner & 0 & 0.0 & excluded & excluded \\
\hline & Light & 9 & 9.7 & $0.53(0.25-1.10)$ & 0.092 \\
\hline & Moderate & 19 & 16.1 & $0.96(0.55-1.65)$ & 0.882 \\
\hline & Intense & 85 & 16.7 & 1.00 & \\
\hline
\end{tabular}

Chi-square, $\mathrm{p}<0.1$, CI 95\% 
Table 3 - Univariate analisys of pshycological workload and socio-demographics caractheristics (Gross Odds Ratio)

\begin{tabular}{|c|c|c|c|c|c|}
\hline $\mathrm{N}=703$ & & $\begin{array}{l}\text { Frequency } \\
\text { (absolute } \\
\text { number) }\end{array}$ & $\begin{array}{c}\text { Prevalence } \\
\%\end{array}$ & $\begin{array}{c}\text { Gross OR } \\
(\text { CI 95\%) }\end{array}$ & $p$ \\
\hline \multirow[t]{3}{*}{ Sex } & & & & & 0.067 \\
\hline & Female & 41 & 20.1 & $1.59(0.96-2.61)$ & 0.068 \\
\hline & Male & 34 & 13.7 & 1.00 & \\
\hline \multirow[t]{4}{*}{ Age } & & & & & 0.351 \\
\hline & Elder & 3 & 17.6 & $1.34(0.36-5.00)$ & 0.654 \\
\hline & Middle age & 45 & 18.8 & $1.46(0.86-2.45)$ & 0.153 \\
\hline & Young adult & 27 & 13.7 & 1.00 & \\
\hline \multirow[t]{4}{*}{ Skin color } & & & & & 0.709 \\
\hline & Dark & 18 & 18.6 & $1.06(0.55-2.07)$ & 0.844 \\
\hline & Mulatto & 31 & 15.1 & $0.83(0.47-1.47)$ & 0.538 \\
\hline & White & 26 & 17.6 & 1.00 & \\
\hline \multirow{5}{*}{$\begin{array}{l}\text { Conjugal } \\
\text { situation }\end{array}$} & & & & & 0.891 \\
\hline & Widower & 2 & 20.0 & $1.20(0.24-5.84)$ & 0.815 \\
\hline & Separate/divorciate & 3 & 15.8 & $0.90(0.25-3.21)$ & 0.878 \\
\hline & Single & 17 & 14.3 & $0.80(0.44-1.45)$ & 0.473 \\
\hline & Married & 52 & 17.2 & 1.00 & \\
\hline \multirow[t]{4}{*}{ Social class } & & & & & 0.236 \\
\hline & High & 15 & 23.1 & $1.88(0.91-3.87)$ & 0.084 \\
\hline & Middle & 34 & 16.5 & $1.24(0.70-2.19)$ & 0.450 \\
\hline & Low & 24 & 13.7 & 1.00 & \\
\hline \multirow{4}{*}{$\begin{array}{l}\text { Educational } \\
\text { level }\end{array}$} & & & & & 0.539 \\
\hline & Low & 14 & 15.9 & $0.67(0.28-1.59)$ & 0.374 \\
\hline & Middle & 48 & 15.6 & $0.66(0.32-1.35)$ & 0.259 \\
\hline & High & 12 & 21.8 & 1.00 & \\
\hline \multirow[t]{4}{*}{ Smoking } & & & & & 0.288 \\
\hline & Smoker & 11 & 11.7 & $0.63(0.31-1.28)$ & 0.209 \\
\hline & Ex-smoker & 16 & 20.0 & $1.20(0.64-2.25)$ & 0.565 \\
\hline & No smoker & 48 & 17.2 & 1.00 & \\
\hline \multirow[t]{4}{*}{ Alcohol } & & & & & 0.271 \\
\hline & Excessive consumer & 5 & 17.2 & $0.89(0.32-2.48)$ & 0.836 \\
\hline & Moderate consumer & 24 & 13.0 & $0.64(0.37-1.10)$ & 0.112 \\
\hline & No drinker & 45 & 18.8 & 1.00 & \\
\hline \multirow[t]{3}{*}{ Central Obesity } & & & & & 0.993 \\
\hline & Yes & 17 & 17.2 & $1.02(0.56-1.85)$ & 0.993 \\
\hline & No & 58 & 16.8 & 1.00 & \\
\hline \multirow[t]{5}{*}{ Physical activity } & & & & & 0.486 \\
\hline & No practitioner & 0 & 0.0 & excluded & excluded \\
\hline & Light & 11 & 12.5 & $0.69(0.34-1.41)$ & 0.320 \\
\hline & Moderate & 17 & 18.7 & $1.12(0.60-2.07)$ & 0.710 \\
\hline & Intense & 46 & 17.0 & 1.00 & \\
\hline
\end{tabular}

Chi-square, p<0.1, CI 95\% 
Table 4 - Univariate analisys of mixed workload and socio-demographics caractheristics (Gross Odds Ratio)

\begin{tabular}{|c|c|c|c|c|c|}
\hline $\mathrm{N}=108$ & & $\begin{array}{c}\text { Frequency } \\
\text { (absolute } \\
\text { number) }\end{array}$ & $\begin{array}{c}\text { Prevalence } \\
\%\end{array}$ & $\begin{array}{c}\text { Gross OR } \\
\text { (CI 95\%) }\end{array}$ & $p$ \\
\hline \multirow[t]{3}{*}{ Sex } & & & & & 0.937 \\
\hline & Female & 6 & 18.2 & $0.95(0.28-3.18)$ & 0.937 \\
\hline & Male & 7 & 18.9 & 1.00 & \\
\hline \multirow[t]{4}{*}{ Age } & & & & & 0.618 \\
\hline & Elder & 0 & 0.0 & excluded & excluded \\
\hline & Middle age & 6 & 21.4 & $1.36(0.40-4.59)$ & 0.617 \\
\hline & Young adult & 7 & 16.7 & 1.00 & \\
\hline \multirow[t]{4}{*}{ Skin color } & & & & & 0.542 \\
\hline & Dark & 5 & 21.7 & $2.36(0.40-13.88)$ & 0.341 \\
\hline & Mulatto & 6 & 21.4 & $2.31(0.41-12.95)$ & 0.338 \\
\hline & White & 2 & 10.5 & 1.00 & \\
\hline \multirow{5}{*}{$\begin{array}{l}\text { Conjugal } \\
\text { situation }\end{array}$} & & & & & 0.092 \\
\hline & Widower & 0 & 0.0 & excluded & excluded \\
\hline & Separate/divorciate. & 1 & 33.3 & $1.55(0.12-18.95)$ & 0.732 \\
\hline & Single & 1 & 4.8 & $0.15(0.01-1.30)$ & 0.086 \\
\hline & Married & 10 & 24.4 & 1.00 & \\
\hline \multirow[t]{4}{*}{ Social class } & & & & & 0.257 \\
\hline & High & 2 & 22.2 & $2.21(0.33-14.58)$ & 0.409 \\
\hline & Middle & 7 & 28.0 & $3.01(0.77-11.72)$ & 0.112 \\
\hline & Low & 4 & 11.4 & 1.00 & \\
\hline \multirow{4}{*}{$\begin{array}{l}\text { Educational } \\
\text { level }\end{array}$} & & & & & 0.337 \\
\hline & Low & 3 & 16.7 & $0.20(0.02-2.03)$ & 0.174 \\
\hline & Middle & 8 & 16.7 & $0.20(0.02-1.63)$ & 0.133 \\
\hline & High & 2 & 50.0 & 1.00 & \\
\hline \multirow[t]{4}{*}{ Smoking } & & & & & 0.633 \\
\hline & Smoker & 1 & 9.1 & $0.40(0.04-3.50)$ & 0.408 \\
\hline & Ex-smoker & 2 & 22.2 & $1.14(0.20-6.36)$ & 0.879 \\
\hline & No smoker & 10 & 20.0 & 1.00 & \\
\hline \multirow[t]{4}{*}{ Alcohol } & & & & & 0.948 \\
\hline & Excessive consumer & 1 & 25.0 & $1.50(0.13-16.35)$ & 0.739 \\
\hline & Moderate consumer & 4 & 18.2 & $1.00(0.26-3.76)$ & 1.000 \\
\hline & No drinker & 8 & 18.2 & 1.00 & \\
\hline \multirow[t]{3}{*}{ Central Obesity } & & & & & 0.873 \\
\hline & Yes & 3 & 20.0 & $1.12(0.26-4.74)$ & 0.873 \\
\hline & No & 10 & 18.2 & 1.00 & \\
\hline \multirow[t]{5}{*}{ Physical activity } & & & & & 0.543 \\
\hline & No practitioner & 0 & 0.0 & excluded & excluded \\
\hline & Light & 2 & 11.1 & $0.50(0.09-2.58)$ & 0.408 \\
\hline & Moderate & 2 & 28.6 & $1.60(0.26-9.63)$ & 0.608 \\
\hline & Intense & 9 & 20.0 & 1.00 & \\
\hline
\end{tabular}

Chi-square, $\mathrm{p}<0.1$, CI $95 \%$

When multivariate analysis was performed (Table 5), belonging to the female sex and being widowed remained as predictors for the development of NULP in individuals that had a predominantly physical workload. Moderate alcohol consumption also continued to be a protector. However, no statistically significant associations were observed in the psychological load group. 
Table 5 - Multivariate analysis of worload and socio-demographifics

\begin{tabular}{|c|c|c|c|c|c|}
\hline $\mathrm{N}=1981$ & & $\begin{array}{c}\text { Physical } \\
\text { Adjusted OR } \\
\text { (IC 95\%) }\end{array}$ & $p$ & $\begin{array}{l}\text { Pshycological } \\
\text { Adjusted OR } \\
\text { (IC 95\%) }\end{array}$ & $p$ \\
\hline \multirow[t]{3}{*}{ Sex } & & & $\mathbf{0 . 0 3 3}$ & & 0.088 \\
\hline & Female & $1.67(1.03-2.71)$ & $\mathbf{0 . 0 3 5}$ & $1.71(0.91-3.20)$ & 0.090 \\
\hline & Male & 1.00 & & 1.00 & \\
\hline \multirow[t]{4}{*}{ Age } & & & 0.449 & & 0.392 \\
\hline & Elder & $0.68(0.26-1.73)$ & 0.423 & $0.95(0.19-4.74)$ & 0.954 \\
\hline & Middle age & $1.14(0.70-1.88)$ & 0.581 & $1.50(0.79-2.82)$ & 0.209 \\
\hline & Young adult & 1.00 & & 1.00 & \\
\hline \multirow[t]{4}{*}{ Skin color } & & & 0.684 & & 0.843 \\
\hline & Dark & $1.28(0.72-2.28)$ & 0.392 & $1.11(0.53-2.34)$ & 0.772 \\
\hline & Mulatto & $1.11(0.64-1.91)$ & 0.695 & $0.90(0.48-1.69)$ & 0.760 \\
\hline & White & 1.00 & & 1.00 & \\
\hline \multirow[t]{5}{*}{ Conjugal situation } & & & 0.210 & & 0.934 \\
\hline & Widower & $2.46(1.02-5.96)$ & 0.045 & $0.99(0.16-6.15)$ & 0,994 \\
\hline & Separate/divorciate & $1.32(0.48-3.61)$ & 0.582 & $0.71(0.18-2.71)$ & 0,622 \\
\hline & Single & $1.31(0.79-2.17)$ & 0.281 & $0.85(0.42-1.70)$ & 0,658 \\
\hline & Married & 1.00 & & 1.00 & \\
\hline \multirow[t]{4}{*}{ Social class } & & & 0.345 & & 0.748 \\
\hline & High & $2.28(0.71-7.26)$ & 0.163 & $1.40(0.57-3.48)$ & 0.458 \\
\hline & Middle & $1.21(0.75-1.96)$ & 0.422 & $1.06(0.56-2.02)$ & 0.839 \\
\hline & Low & 1.00 & & 1.00 & \\
\hline \multirow[t]{4}{*}{ Educational level } & & & 0.549 & & 0.646 \\
\hline & Low & $1.10(0.25-4.71)$ & 0.895 & $0.87(0.31-2.40)$ & 0.794 \\
\hline & Middle & $0.85(0.20-3.59)$ & 0.830 & $0.70(0.30-1.63)$ & 0.412 \\
\hline & High & 1.00 & & 1.00 & \\
\hline \multirow[t]{4}{*}{ Smoking } & & & 0.385 & & 0.798 \\
\hline & Smoker & $1.42(0.85-2.37)$ & 0.174 & $0.82(0.38-1.76)$ & 0.612 \\
\hline & Ex-smoker & $1.24(0.66-2.33)$ & 0.494 & $1.10(0.54-2.25)$ & 0.778 \\
\hline & No smoker & 1.00 & & 1.00 & \\
\hline \multirow[t]{4}{*}{ Alcohol } & & & 0.020 & & 0.472 \\
\hline & Excessive consumer & $1.37(0.54-3.46)$ & 0.503 & $0.97(0.32-2.91)$ & 0.969 \\
\hline & Moderate consumer & $0.54(0.32-0.89)$ & 0.016 & $0.69(0.37-1.27)$ & 0.236 \\
\hline & No drinker & 1.00 & & 1.00 & \\
\hline \multirow{5}{*}{ Physical activity } & & & 0.925 & & 0.892 \\
\hline & No practitioner & excluded & - & excluded & - \\
\hline & Light & $0.85(0.38-1.91)$ & 0.708 & $1.20(0.53-2.70)$ & 0.661 \\
\hline & Moderate & $0.94(0.52-1.70)$ & 0.849 & $1.10(0.55-2.22)$ & 0.772 \\
\hline & Intense & 1.00 & & 1.00 & \\
\hline
\end{tabular}

Physical: Chi-square $=30.354, \mathrm{p}=0.034$, CI 95\%

Psychological: Chi-square $=13.521, \mathrm{p}=0.760$, CI 95\%

\section{DISCUSSION}

In this study, the prevalence of neck pain was high $(9.47 \%)$ in the general population, without the possibility of making comparisons, as the studies observed in the literature were conducted in specific populations of workers. ${ }^{(4,5,9,15,16,17)}$ In population with high occupational risk, variations in prevalence from 20 to $40 \%$ were observed..$^{(5,16,17,18,19)}$ In these studies associations between time of service in the function and high physical load were common, ${ }^{(4)}$ with frequent repetitiveness of tasks and excessive force. ${ }^{(15)}$ Palmer et al. ${ }^{(20)}$ investigated the prevalence of neck pain and its association with occupational activities, at a populational level 
in England, Scotland and Wales, and observed that neck pains were more associated with headaches and stress than with the occupational activity.

Mixed load in the present study only presented association with the marital status of single, but as a protective factor. The groups of predominantly physical and psychic load were affected in a different manner. While for physical load, the predictors found were female sex and widowed situation, for psychic loads being a woman was sustained as a predictor. However, belonging to a high social class appeared as a predictor which, although it had not been maintained in an independent manner in the multivariate analysis, deserves attention. It is worth emphasizing that the interfaces of cause-and-effect of sectional studies must be analyzed with caution, in spite of findings suggesting that prevention needs to involve the population in general, pointing towards exposure to the occupational risk. ${ }^{(5)}$

The higher prevalence of moderate and severe NULP is found in women in several studies, in agreement with the findings of this study. ${ }^{(4,12,15,17)}$ High exposure to mechanical loads was associated with increased risk of pain in the cervical region and shoulders in the study of Ostergren et al., ${ }^{(21)}$ who concluded that psychological demands and low freedom to make decisions were correlated with the risk of developing pain in the region in women and could be potentiated by mechanical exposure and psychosocial factors. Mechanical exposure causes pain in both sexes, while psychosocial factors appear to predispose women more to the development of this type of pain. This information can partially explain the involvement of women of high social class in the group with predominantly psychic load found in the present study.

All studies confirmed that the age group most affected is the one over the age of 30 years. ${ }^{(4,17)}$ This can be justified by chronic exposure associated with wear of the musculoskeletal system as a result of aging. Although no statistically significant associations with age were observed in the present study, it was verified that the prevalence of NULP had a high OR in the 30 to 64 year-old group, coinciding with the study of Monteiro et al. ${ }^{(12)}$ Analysis of this factor must be made with caution, as many individuals affected by dysfunction in the cervical region and upper limbs could retire early, and this could influence the results, underestimating the number affected as from the age of 45 years. ${ }^{(21)}$ At any rate, the findings suggest that prevention strategies should be started early.

That psychic loads are significantly associated with the high social class draws ones attention. One also noted that the higher social class presented a higher OR than the low class both in physical and psychic load. Whereas for mixed load, the OR was higher in the middle 
class. Gillen et al. ${ }^{(22)}$ studied hospital workers under a combination of socio-economic, organizational, psychosocial and physical factors. In their study the risk of developing NULP was more strongly influenced by psychosocial and physical exposures than by socioeconomic factors, such as educational level. Monteiro et al. ${ }^{(12)}$ observed that the educational level also influenced the algic behavior of workers, although the stratum of medium educational level had been the most affected. Perhaps persons with medium educational level concentrate a larger number of persons exposed to mixed tasks, as in the case of telemarketing operators. Whereas, persons of low educational level seem to be more exposed to physical loads and those of high educational level to psychic loads. Russel et al. ${ }^{(23)}$ found association of pain with low income and low educational level, and also observed that having a higher income and a higher educational level were protective factors. The role of psychosocial and organizational questions has been increasingly determinant in the development of painful processes in workers.

In the literature, race/ethnicity is not a factor associated with the presence of pain. Only Wang et al. ${ }^{(4)}$ found greater prevalence among Hispanics, but their study was conducted in a population of industrial seamstresses that presented very specific occupational characteristics.

Smoking is a risk factor described for musculoskeletal, ${ }^{(24)}$ but not detected in this study. Whereas alcohol consumption, which is recognized as predictive factor for the development of musculoskeletal pain, ${ }^{(25)}$ was also not shown to be an independent predictor. Moderate consumption appeared to be associated with less chance of developing pain in individuals with a predominantly physical load. The influence of alcohol consumption on endogenous analgesic mechanisms mediated by opioid activity it known. ${ }^{(26,27)}$ It is possible that in moderate doses it can lead to reduction in the discomfort resulting from intense exposure to physical loads, serve as positive reinforcement (source of pleasurable sensations) or diminish stress and possibly pain, ${ }^{(28)}$ although there is lack of concrete evidence in this connection.

The practice of physical activities can be a determinant factor in the presence of NULP, ${ }^{(29,30)}$ but normally, studies on the subject concern intervention, in which specific program are developed. In this study, no association with this factor was observed, probably because of the lack of an adequate instrument for evaluation the physical activities of labor, especially since it concerns a sample of predominantly low socio-economic level. 
One of the limitations of the present study was not evaluating psychological factors, such as depression and anxiety. As the reliability of the instruments of evaluation of this aspect is controversial, it was opted not to include data analysis of this factor. Some authors mentioned that the self-report on depression could be subject to important biases, which make it difficult to evaluate pain related to other factors of risk in subjects with chronic pain. ${ }^{(31)}$ Nevertheless, it is described in the literature that the low level of work satisfaction ${ }^{(4,19,32)}$ and reduction in quality of life ${ }^{(15)}$ may be associated with the presence of pain in workers, and is pointed out as the greatest causes of the development of musculoskeletal pain. It is believed that workers more exposed to physical and psychosocial factors are more predisposed to develop musculoskeletal disorders of the cervical region and upper limbs than those that are exposed to only one or other factor. Ergonomic intervention strategies should develop the minimization of physical as well as psychosocial risks. ${ }^{(7)}$ However, the regional behavioral profile has characteristics that are strongly influenced by regional culture and art and no instrument validated in this population was found, which would guarantee internal consistency and reliability of the data. ${ }^{(6)}$

In conclusion, the present study found a prevalence of $9.4 \%$ of pain in the cervical region or in upper limbs in a populational sample. Investigating factors associated with its present, it found that when individuals perform predominantly physical activities, the associated variables were belonging to the female sex and being widowed. For predominantly psychic activities, being a woman and belonging to a high social class were predictors, although social class was not sustained in the multivariate analysis. Moderate alcohol consumption for physical loads and being single for mixed loads were also observed as protective factors.

It is believed that these basic data, although they present limitations inherent to sectional population studies, may contribute as foundation for more specific, longitudinal population study designs, with the goal of finding out about the worker's health and clinical trials, in addition to generating data for intervention strategies in health programs.

\section{ACKNOWLEDGMENTS}

This work was funded by the National Health Council -"Fundação Nacional de Saúde”, MS, process number 25100004122;98-91 and CNPq process number 473610;03-5. There was no association with any financial or other relationships which might lead to conflict of interests. This manuscript is part of $\mathrm{PhD}$ thesis from first autor. 


\section{REFERENCES}

1. Böckerman P, Ilmakunnas, P. Interaction of working conditions, job satisfaction, and sickness absences: Evidence from a representative sample of employees. Soc Sci Med 2008; May 26 [Epub ahead of print].

2. Lacaz FA. The workers's health field: reclaiming knowledge and practices in the interface between work and health. Cad Saude Publica 2007;23:757-66.

3. Carayon P, Alvarado CJ. Workload and patient safety among critical care nurses. Crit Care Nurs Clin North Am. 2007;19:121-9.

4. Wang PC, Rempel D, Harrison R, Chan J, Ritz B. Work-organizational and personal factors associated with upper body musculoskeletal disorders among sewing machine operators. Occup Environ Med. 2007;May 23 [Epub ahead of print].

5. Sim J, Lacey RJ, Lewis M. The impact of workplace risk factors on the occurrence of neck and upper limb pain: a general population study. BMC Public Health. 2006;6:234.

6. Bongers PM, Ijimker S, Van Den Heuvel S, Blatter BM. Epidemiology of work related neck and upper limb problems: psychosocial and personal risk factors (part I) and effective interventions from a bio behavioural perspective (part II). J Occup Rehabil. 2006;16:279-302.

7. Devereux JJ, Vlachonikolis IG, Buckle PW. Epidemiological study to investigate potential interaction between physical and psychosocial factors at work that may increase the risk of symptoms of musculoskeletal disorder of the neck and upper limb. Occup Environ Med. 2002;59:269-77.

8. Crombie IK, Croft PR, Linton SJ, Leresche L, Von Korff M. Epidemiology of pain. IASP Press. Seattle:1999. 321p.

9. Eltayeb S, Staal JB, Kennes J, Lamberts PHG, Bie RA. Prevalence of complaints of arm, neck and shoulder among computer office workers and psychometric evaluation of a risk factor questionnaire. BMC Musculeskelet Disord. 2007;68:1-11.

10. Ariëns GA, Bongers PM, Hoogendoorn WE, Van Mechelen W. High physical and psychosocial load at work and sickness absence due to neck pain. Scand J Work Environ Health. 2002;28:222-31.

11. Coggon D, Palmer K.T, Walker-Bone K. Occupation and Upper Limb Disorders. Rheumatology (Oxford). 2000;39:1057-9.

12. Monteiro MS, Alexandre NMC, Rodrigues CM. Doenças músculo-esqueléticas, trabalho e estilo de vida entre trabalhos de uma instituição pública de saúde. Rev Esc Enferm USP. 2006;40:20-5.

13. Lessa I, Magalhães L, Araujo MJ, Almeida Filho N, Aquino E, Oliveira MMC. Arterial Hypertension in Adult Population of Salvador (BA) Brazil. Arq Bras Cardiol 2006; 87:74756. 
14. Palmer ML, Epler ME. Fundamentals of Musculoskeletal Assessment Techniques. J.B. Lippincott Company, 1990:34-41.

15. Andersen JH, Kaergaard A, Frost P, Thomsen JF, Bonde JP, Fallentin N et al. Physical, psychosocial, and individual risk factors for neck/shoulder pain with pressure tenderness in the muscles among workers performing monotonous, repetitive work. Spine 2002;27:660-7.

16. Krause N, Scherzer T, Rugulies R. Physical workload, work intensification, and prevalence of pain in low wage workers: results from a participatory research project with hotel room cleaners in Las Vegas. Am J Ind Med. 2005;48:326-37.

17. Cagnie B, Danneels L, Van Tiggelen D, De Loose V, Cambier D. Individual and work related risk factors for neck pain among office workers: a cross sectional study. Eur Spine J. 2007;16:679-86.

18. Van Den Heuvel SG, Van Der Beek AJ, Blatter BM, Hoogendoorn WE, Bongers PM. Psychosocial work characteristics in relation to neck and upper limb symptoms. Pain. 2005;114:47-53.

19. Johnston V, Jimmieson NL, Souvlis T, Jull G. Interaction of psychosocial risk factors explain increased neck problems among female office workers. Pain. 2007;129:311-20.

20. Palmer KT, Walker-Bone K, Griffin MJ, ET AL. Prevalence and occupational associations of neck pain in the British population. Scand J Work Environ Health.2001;27:4956.

21. Ostergren PO, Hanson BS, Balogh I, Ektor-Andersen J, Isacsson A, Orbaek P, et al. Malmö Shoulder Neck Study Group. Incidence of shoulder and neck pain in a working population: effect modification between mechanical and psychosocial exposures at work? Results from a one year follow up of the Malmö shoulder and neck study cohort. J Epidemiol Community Health.2005;59:721-8.

22. Gillen M, Yen IH, Trupin L, Swig L, Rugulies R, Mullen K et al. The association of socioeconomic status and psychosocial and physical workplace factors with musculoskeletal injury in hospital workers. Am J Ind Med. 2007;50:245-60.

23. Portenoy RK, Ugarte C, Fuller I, Haas G. Population-based survey of pain in the united states: Differences among white, african american, and hispanic subjects. J Pain. 2004;5:31728.

24. Fishbain DA, Lewis JE, Cole B, Cutler RB, Rosomoff HL, Rosomoff RS. Variables Associated with Current Smoking Status in Chronic Pain Patients. Pain Med 2007; 8: 301311.

25. Penny L, Brennam KK, Schutte HM. Pain and use of alcohol to manage pain: prevalence and 3-year outcomes among older problem and non-problem drinkers. Addiction. 2005;100: 777. 
26. Xiao C, Zhang J, Krnjevic K, Ye JH. Effects of ethanol on midbrain neurons: role of opioid receptors. Alcohol Clin Exp Res. 2007;31:1106-13.

27. Xiao C, Ye JH. Ethanol dualy modulates GABAergic synaptic transmission onto dopaminergic neurons in ventral tegmental area: Role of mu-opioid receptors. Neuroscience. 2008 22;153(1):240-8.

28. Eckardt MJ, File SE, Gessa GL, Grant KA, Guerri C, Hoffman PL, et al. Effects of moderate alcohol consumption on the central nervous system. Alcohol Clin Exp Res. 1998;22:998-1040.

29. Mattila R, Malmivaara A, Kastarinen M, Kivelä SL, Nissinen A. Effects of lifestyle intervention on neck, shoulder, elbow and wrist symptoms. Scan J Work Environ Health. 2004;30:191-8.

30. Bernaards CM, Ariëns GA, Knol DL, Hildebrandt VH. The effectiveness of a work style intervention and a lifestyle physical activity intervention on the recovery from nech and upper limb symptoms in computer workers. Pain. 2007;132:142-53.

31. Alschuler KN, Theisen-Goodvich ME, Haig EJ, Geisser ME. A comparison of the relationship between depression, perceived disability, and physical performance in persons with chronic pain. Eur J Pain. 2008 12(6):757-764.

32. Karels CH, Bierma-Zeinstra SM, Burdorf A, Verhagen AP, Nauta AP, Koes BW. Social and psychological factors influenced the course of arm, neck and shoulder complaints. J Clin Epidemiol. 2007;60:839-48. 